\title{
CLASH OF GIANTS - THE CHANGE OF INTERNAL HIGHER EDUCATION GOVERNANCE IN LATVIA
}

\author{
Jānis Bernāts' , Agnese Rusakova², Elmīra Zariṇa² \\ ${ }^{1}$ Riga Stradins University, Latvia \\ ${ }^{2}$ University of Latvia, Latvia
}

\begin{abstract}
Globalization, the transfer to knowledge society exposes the environment of higher education institutions (HEIs) to increasingly complex operating conditions. The universities have to address additional demanding tasks with often-staggering public funding at their disposal.

The paper aims to depict the interaction of government - managers - and higher education (HE) sector - employees - in the context of recent university governance reforms, which in its essence is another manifestation of managerialist policy followed by the government.

The paper starts with contextual information on the HE system in Latvia and its antecedently limited public funding. It then touches the introduction of the performance-based funding model. The review of the funding model came as a reaction to dramatic public funding cuts within the higher education sector that were triggered by the economic crisis 2009-2012. The paper outlines the expectations of the higher education sector that additional public funding will be invested as soon as the new funding model is implemented. However, quite surprisingly for the higher education sector, the newly elected government decides to reform the internal governance of public higher education institutions instead.

The depicted context is analyzed against the concept of managerialism and its influence on the higher education sector, specifically on the deterioration of collegiality as the traditional form of university governance. The paper explains, why the plans to reform the university governance in Latvia by introducing university boards with external stakeholders represented there have been met ambiguously by the higher education sector. The authors seek to answer the seemingly irrational series of actions taken by the Latvian government and do so referring to phenomena of managerial ideology, as well as cautions against the rule of uncompromising, forthright managerialism within the public sector.

The article finds, however, that pure collegiality is no longer viable in the higher education sector in Latvia, and different manifestations of managerialism are there to stay in the higher education sector. Therefore, ways need to be found to adopt and draw benefits from the induced changes. Understanding the rational reasons behind seemingly irrational reforms introduced by the government is the first step in this direction. The next step, but this would be then the subject of further researches, would be to detect the conditions in which the incoming managerialism may undermine or reinforce the quality of higher education.
\end{abstract}


Keywords: boards, collegiality, funding, governance, managerialism, neoliberalism, new public management, university.

\section{Introduction}

\section{Almost quasi-market system}

When classifying the varying historical university models in Europe and estimating the direction of change that the analyzed countries take, it was estimated that due to the factors of change "Adaptation to the market economy and its needs; Unclear role of the state; Increasing demand for HE" the HE systems of Eastern European countries like Poland, Russia and Moldova can be best characterized as "Transition system with fast transformations towards market model (private sector)" (Koivula, \& Rinne, 2008, p. 267). Using this classification, Latvia has surpassed minor orientation towards the market model that according to Koivula \& Rinne characterizes Spain, Finland, Sweden - a "State system with some transformations towards market model" (Koivula, \& Rinne, 2008, p. 268). and can be appropriated as quite close to the "quasi-market system". This estimation is based on a range of factors. Similarly like in the United Kingdom, the state encouraged and keeps encouraging the higher education institutions in Latvia to generate funding from non-state sources. Latvia, where 27 public HEIs and 19 private HEIs coexist, is one of the largest private HE sectors in the region (Pachuashvili, 2009). Furthermore, the Latvian higher education sector is characterized by a dual-funding system - also at public universities the studies are only partly state-supported and almost $40 \%$ of students pay a full tuition fee there (Ministry of Education and Science, Report 2019). The attraction of fee-paying students is one of the income-generating strategies. The tuition fees in the country through the public co-funding are considerably lower than they would be in case the system would be fully quasi-market oriented. However, since the income level of the population leaves it struggling to cover the full tuition fee, a loan support system has been established, that allows money inflow into the system from the bank sector. At the same time, the money available through the bank sector is capped to avoid the tuition fee rise as an adverse effect.

\section{System in decline, system in need}

"Despite a modest but sustained positive public funding trend since impressive budget cut in 2012, the effects of the large budget cuts applied in economic crisis 2009-2012 are still felt by Latvian universities": according to the Public Funding Observatory in 2019 (Bennetot Pruvot, Estermann, \& Kupriyanova, 2020, p. 33). It has characterized Latvia as "system in decline, system in need" (Bennetot Pruvot et al., 2020, p. 33) due to funding decrease higher 
than the actual student numbers decline. However, in Latvia's case of a dual-funding system number of study places has broadly remained stable, while the student body decline is mostly due to a lower number of fee-paying students. At times of public funding austerity, the public institutions have been therefore hit both by the decline in public funding and by lower income from tuition fees.

The ongoing globalization of the higher education sector places the HEI in an increasingly competitive external and internal environment. In addition to teaching and research, modern universities have additional contemporary tasks like nurturing and taking care of eco-systems, commercializing the science, just to name a few. These new tasks rarely come with additional funding. These new roles of the university, which are brought by through the unfolding of the knowledge society, are merely claimed to be just self-evident need for the universities to change over time. All of this brings the system in money shortage, while more and more compromises with basic academic values have to be taken.

Following the perspective, that there is a "need for rationalization and quality improvement and better use of tuition fees" (Aslund, \& Dombrovskis, 2011, p. 73) in the higher education sector, a series of reforms were intended to address these needs. These additional performances and quality improvement-oriented tasks were specified by conventional amendments to the Law on Higher Education Institutions ("Grozijumi Augstskolu likumā" 2011) and this concurrently with the harsh public funding cuts, as high as $48 \%$ at the beginning of 2009 and a further cut of 18\% in 2010 (European University Association, 2011), resulting from economic crisis 2009-2012.

Within this context, all higher education stakeholders were that much united in the understanding, that public funding share in higher education must be increased, that this social agreement was fixed in Law on Higher Education Institutions by its amendments ("Grozijumi Augstskolu likumā" 2011) as early as in 2011. However, much to the distress of the higher education sector, the public funding increment rate, fixed in the law to be $0.25 \%$ of gross domestic product each year, was never put in effect, as a matter of fact, leaving the sector struggling with the need of restructuring following new circumstances imposed by greater demands to the sector and simultaneous lack of resources.

\section{Introduction of performance-based higher education funding model}

To address the abovementioned issue shortly after the economic crisis in 2009-2012, in 2015 a new higher education funding model in Latvia has been introduced. The concept has been elaborated in 2014 by the World Bank 
as part of World Bank Reimbursable Advisory Service on Higher Education Financing in Latvia to "help Latvia achieve its objectives, such as enhanced quality of teaching and research, greater efficiency, access, and internationalization, and stimulate innovation, entrepreneurship and staff development," (World Bank, 2014, p. 25). The World Bank experts conclude that the current public funding model in Latvia is mainly an investment-oriented "one pillar" model, which does not ensure a balance between stability, performance, and innovation orientation. "While, in principle, public funds are allocated according to study places, i. e., educational needs, this is de-facto nearly the only public funding instrument, and thus has to accommodate many competing needs (partially related to research and wider institutional missions) of universities," (World Bank, 2014, p. 16). Therefore, the experts proposed adopting a "three pillar" model instead, where the $\left[1^{\text {st }}\right.$ pillar] base funding ensures the sustainability of the system, the $\left[2^{\text {nd }}\right.$ pillar $]$ performance funding promotes the achievement of results, while the [ $3^{\text {rd }}$ pillar] development funding promotes the connection with the long-term economic development needs.

During 21 months, apart from many HEI, more than 30 stakeholders have been interviewed and the "stakeholder consultations played a vital role in the project methodology" (Arnhold, Kivistö, Vossensteyn, Weaver, \& Ziegele, 2018a, p. 237). After this kind of rather tight interaction with the higher education sector of Latvia, citing the final report - "The World Bank team is convinced that all stakeholders in Latvian higher education have a strong interest in the enhancement of the higher education sector in terms of quality, efficiency, strategic orientation, international competitiveness and equity," (Arnhold et al., 2018a, p. 280).

So how did it happen that just a couple of years later the conflict between the stakeholders who all are united by the same values escalated as to two reputable stakeholders requesting the resignation of the minister (“Arī Rektoru padome prasa" 2021)?

\section{Method}

To answer this question a retrospective analysis of series of events is conducted, with the culmination point being the recent reforms of the higher education governance in Latvia. This longitudinal case analysis uses the elements of historiography - highlighting particular details in the form of exact citations from authentic and validated secondary sources. These details are synthesized into a compelling narrative form. The exhibited compilation of events taking place at multiple follow-up times represents the analyzed longitudinal data.

Close attention is paid to the temporal component and the related qualitative content of the event as related to the analyzed context. To add depth 
to the study the authors illustrate the context through texts from several directly related, even causal, comprehensive researches on the higher education sector in Latvia conducted by the World Bank, as well as other secondary data such as news articles, governmental and international comparative reports from validated authors such European Commission, European University Association.

The process tracing is applied to dissect the causal triggers and mechanisms unveiling the higher education sector's transition to a new form of university governance.

The longitudinal data are analyzed to disclose the underlying clash of collegiality and managerialism.

\section{Results}

\section{University Governance Reform}

The university governance became the new major reform focus of the government soon after the elections in 2018. This earnest undertaking however came impulsively, as it was not envisaged in the declaration of the Cabinet of Ministers at the moment of its formation in early 2019. Instead, it increased the demands for the higher education sector by setting the ambitious benchmark of inclusion of at least one Latvian university among the top 500 universities globally (Deklarācija par Artura Krišjāņa Kariņa vadītā Ministru kabineta iecerēto darbību, 2019, p. 15). The academic community continued expecting a rationally consecutive and planned full implementation of the new funding model, as also stated by the abovementioned government declaration: "Ensuring an increase in state budget funding for the efficient operation of the three-pillar model" (Deklarācija par Artura Krišjānna Karinna vadītā Ministru kabineta iecerēto darbību, 2019, p. 15).

Thus in 2019, the European Commission speaks of the new government having pledged "to ensuring financial support to the three-pillar funding model" (Education and Training Monitor 2019, 2019, p. 8). Nevertheless in 2020, according to a publication on the official website of the Ministry of Education and Science, the three-pillar funding model, that has been approved by the Cabinet of Ministers in 2015, still lacks funding for the third pillar.

While in 2014 the World Bank already asserts: "the system is significantly underfunded in comparison to not only other European countries but, importantly, also vis-à-vis the government objectives and legally-set targets, both as a proportion of public spending and per study-place" (World Bank, 2014, p. 5), in 2020 the government pertains to even the more arduous aim of "top 500 " even though the liabilities implied by previous social agreement have not yet been attended to in whole - instead of three-pillar funding model 5 
years later there is only funding allocated for the two pillars in fact. While developing the three-pillar funding model the World Bank discouraged from implementing it unless additional funding is allocated: "Without any incremental funds, there is the minimal capacity to reform the financing model," (World Bank, 2014, p. 52). Even more, the World Bank experts warned that: "Allocating fewer or even the same amount of resources differently may create substantial volatility within the system,"(World Bank, 2014, p. 52).

Certainly, the findings do state that Latvia is one of the few OECD countries where external stakeholders are not included in HEIs' governance boards (OECD, 2019) as well as among 8 European higher education systems, where it is not required to include external stakeholders in the internal governance of the institution, in fact, Latvia is even not able to include (Arnhold, N., Kivistö, J., Püttmann, V., Vossensteyn, H., \& Ziegele, F., 2018b). Nonetheless, this does not mean that the internal governance at this point was closed to stakeholder involvement. The experts find that within the existing legal framework "the involvement of internal stakeholders is well-developed in Latvian higher education institutions. This also holds true for students," (Arnhold et al., 2018b, p. 142) and "External stakeholders are involved in the governance of Latvian higher education institutions in different ways, but." following the legal requirements: "..for the most part without formal decision-making rights and responsibilities" (Arnhold et al., 2018b, p. 99). Moreover, the experts even praise the existing system:" Among the most striking features of internal governance in Latvian higher education institutions are the deep-rooted democratic culture and the highly interactive and inclusive decision-making processes on all institutional levels," (Arnhold et al., 2018b, p. 140).

Even though the experts play around the possibility to adjust the governance in Latvia to a modern managerial approach: "Contrasting the current situation in Latvia with developments and practices in other countries, a more formal and systematic way of integrating external stakeholders into governance processes could be beneficial," (Arnhold et al., 2018b, p. 142), however, the experts are not explicitly negative on the existing governance system, as they just suppose that traditional collegial governance structures can hold back the ability of Latvian HEIs to respond swiftly and strategically to changing economic and societal needs (OECD, 2019). Also, concerning the advantages of reforming the governance structures the experts are careful about their statements: "Especially in the Latvian context, where the current governance culture is cherished by many, gradual shifts toward a more managerial, personal responsibility-focused approach that does not destroy the democratic culture is particularly relevant," (Arnhold et al., 2018b, p. 142). or even point out that the optimism about the positive effect of governance boards in European higher education systems in between has diminished:" 
In the course of the increasing involvement of external stakeholders in governance boards, different challenges have become apparent that can limit their positive impact on the development of higher education institutions," (Arnhold et al., 2018b, p. 71)

\section{Discussion}

In this context, the unexpectedly raised higher on the agenda issue of university governance is met ambivalently by the higher education sector. Even though the World Bank experts had proposed certain alignments of the internal governance to the global trends, allowing the HEIs to involve external stakeholders in line with the rest of the world would be sufficient. After all, the HEIs seemed to be open, and involving stakeholders was a commonly represented practice across the HEIs, so the higher education sector understands the benefits of attending to stakeholder's points of view.

At the same time the apparent ignorance of the obviously insufficient funding that the higher education sector had to cope with for decades (the necessity of this investment was underlined as imperative to address by World Bank experts as well), was interpreted by the higher education sector as an allegation that there is already enough money in the system available, one should only govern it more efficiently and this - with help of external stakeholders, since the internal stakeholders, apparently, are unable to do so.

Indeed, neoliberal managerialism enters the higher education in Latvia with attempts to seize the control and power, attempts to measure the performance, also the imperceptible and intrinsic value of academic activities, with explicit and rational indicators - promising Latvian higher education institutions to reach the top 500, and claims that higher education institutions in Latvia are not effectively governed ("On conceptual report "On internal governance reform of the higher education institutions" "2020).

It is clear that incoming managerialism, in order to establish itself in higher education, needs to discredit the existing form of governance - collegiality - a form of established self-governance based on trust and collaborative decision making of communities of scholars of roughly similar intellects and abilities, being at its core value-driven and normative in orientation (Chong et al., 2018).

In its essence: "The main features of managerialist policy are incessant organizational restructuring, sharpening of incentives, and expansion in the number, power, and remuneration of senior managers, with a corresponding downgrading of the role of skilled workers, and particularly of professionals," wrote Quiggin in 2003. 
In line with these characteristics of managerialist policy introduced by Quiggin (2003), the higher education sector in Latvia has undergone series of seemingly incessant reforms aimed at restructuration. As a major structural driver for achieving the goals set by the government the performance-based funding was introduced and gained formidable political support (Dougherty et al., 2014), also in Latvia. Herewith a tool for increased managerial control and command in this public sector has been established. By linking state appropriations, at least a portion of them, directly to institutional outcomes it was declared to address the challenges of, according to the neoliberal view, the underperformance of higher education as the public sector - and simultaneously gain an easy to use tool for accountability purpose.

To gain public support and speed up the deconstruction of the existing form of governance in higher education, a campaign is needed to claim that the existing form of governance is inefficient and that the new form of governance instead will allow achieving the goals shared by all stakeholders.

Public support is necessary for accountability reasons. The owners of capital - the electorate/ the taxpayers - are not in charge of their property as they have commissioned through election procedure the government the managers - to administer the state property and the tax money. With knowledge society advancing, the taxpayers become increasingly aware of the commissioned rights and in exchange they require accountability. With the advancement of the postmodern neoliberal concept also public-sector organizations need to become increasingly accountable or implement accountability measures. After all - in the private sector, everyone is equally accountable to those who have power and money. However, it is far easier to measure productivity in industry, the output created by a lowskilled workforce, than the performance of the intangible value-intensive public sector.

Self-evidently - to be able to defend its existence to the electorate, the government itself needs to understand what its supervised public-sector institutions do. This is not an easy task, as public-sector institutions usually employ highly qualified staff, to attain qualitative goals, so to understand the specifics of the job, one should be a professional of the same field. However, it is highly unrealistic to be that qualified in every field of knowledge, so the managers, on basis of exerting power, require sound and comprehensible evidence that would allow anyone, even non-professionals in the field, to easily judge the performance of the public sector professionals. The focus shifts from mere trust in best performance due to one's proven professionalism, to demonstrable indicators of performance to anybody - any taxpayer - who would seek to question the quality of performance thereof. 
The managers require proofs of efficiency, and the academics supply these proofs, however, both parties measure the efficiency based on a different narrative. With managerialism, the value rationality is replaced by purpose rationality (Rutgers, \& Schreurs, 2006), or as further specified by Klikauer (Klikauer, 2015, p. 107): "For managerialism, there are no democratic solutions to problems, only managerial ones".

In reality, with the existing form of governance - collegiality, the government simply lacks the tools to convincingly demonstrate the quality of its managerial work performance to anyone who would like to question this quality, including own donors. There is a need for clarity, transparency - how each of the system's subjects works under the supervision of managers to achieve the goal. In addition, to be able to support higher education institutions with their competence of goal rationality, the management and monitoring systems are needed that allow management to identify areas of intervention, as well as tools to influence the decision-making process in higher education institutions, like performance-based funding as an instance. Managerialism follows the command-and-control concept of management and the collegial democracy of decision making seems inappropriate in this case. After all "for managerialism, politics and democracy are simply a hindrance on the way to efficiency and competitive advantages." (Klikauer, 2015, p. 107).

Because controlled individuals cannot be trusted by default as they all act in the name of self-interest, in neoliberalism (Hodge et al., 2018), government research in the higher education sector is no longer conducted by sector's experts themselves, but by third parties, interviewing the exactly same higher education experts and retelling to governmental managers what they are saying. In other words, the state increasingly directs public funding to smaller and larger external consultants' organizations that specialize in translating the work done by universities into a procedural language understood by managers. This is a skill that universities have yet to develop, and the new governance system, with a university board represented by many different members of society, to whom the university both administrative and academic staff will have to account daily, will contribute to the development of this skill. At the same time, it demonstrates how in the managerial approach the experts of the field are downsized, merely considered purely in the status of another to be analyzed material inventory, an element of capital - human capital. This is in line with attempts by managerial policy to downgrade the role of skilled workers, and particularly of professionals mentioned earlier in this text.

To facilitate this translation process, there are discourses in the public media cultivated, portraying students as consumers, teachers as service providers, and the higher education sector, as a sector seemingly capable of 
endless efficiency improvements, a sector that ultimately benefits the society only as much as its graduates can earn. Just like Klikauer argues the managerialism "..has led to intellectual and scientific limitations. These limitations mirror corporate limitations when the focus on numbers and mathematical equations eliminates dialectical thinking in favor of one-dimensional thinking," (Klikauer, 2015, p. 115).

While being in an induced by neoliberal ideology spiral of goal rationalism, it is tempting to get into the position where one can decide on the use of money in a controlled entity, make the process of allocating money more transparent to the parties involved, as well as respond to the needs of the sector as per the understanding of existing needs by involved external parties. This is where the university boards become a convenient tool.

If universities may be unwilling to leave their comfort zone and defend their spending against the arguments that are founded by purpose rationalism, then managers may fall into the trap prepared by the neoliberal perpetual drive for efficiency. The demands of the sector for additional investments are rejected antecedently by appeals from managers to improve the efficiency of the existing system first and foremost. The authoritarian management style of managerialism "increases the potential for corporate immorality" (Klikauer, 2015, p. 114), which in the case of Latvia was observable in the circumstances described before - the higher education sector has to fulfill its obligations as per law, whereas the government ignores the social agreement even though it has been fixed in the same law.

As a matter of fact, indeed, it is not effective to invest extra money in an inefficient sector. By using the newly acquired power in this way, the managers have undoubtedly acted rationally at the end of the day by refraining from investing more money into the sector, which they had declared as inefficient. Nonetheless, in the long run, the base of provided services keeps deteriorating and, contrary to expectations, the voices of taxpayers become more dissatisfied. Just like a cow can be milked and not fed for a while - first, those who do care about the cow's exterior will become dissatisfied and then, as time passes, everyone will start complaining.

When introducing accountability solutions in universities, the impact of such measures needs to be carefully considered in advance. At present, an underfunded sector, that has to compete in the European free market will also have to reallocate internal resources to carry out the functions associated with the new form of governance. In systemically larger universities, the effects of governance rooted in managerialism may increase accordingly. For each report requested by the manager, a workload share of the university administrator or academic staff must be diverted. As it is inefficient to redirect the human resources of academic staff to attend to these needs, the number of the administrative staff will be increased, however in 
the end the highly skilled academics most probably will still need to contribute to accountability measures. The administration overhead in higher education systems affected by managerialism will naturally increase, as witnessed by a college in Australia "..restructuring that was supposed to see a far more efficient administration has produced the opposite: a proliferation of middle and upper managers so that administrative costs have ballooned" (Fisher (Kambah), 2012).

Exaggerating systemic problems in public discussions to gain support for intended actions, may not achieve the intended results, despite the great work done by all parties involved in improving the system.

\section{Conclusions}

The standpoint of the former prime minister of Latvia V. Dombrovskis, as acknowledged in his memoir already as early as 2011, that there is a "need for rationalization and quality improvement and better use of tuition fees" (Aslund, \& Dombrovskis, 2011, p. 73) in the higher education sector, lies within the frames of managerialist policy characteristics. It shows the purpose rationalist strive for efficiency and performance. At the same time, it also contains the idiosyncratic to managerialism declaration of "better knowing" of both what is needed and how to manage the funds. The short excerpt clearly demonstrates the managerialist endeavor for greater control and power as it positions the managerialist as an active, sophisticated on the process person, ready to take action to improve things. Simultaneously, it downgrades the professionals at the autonomous higher education institutions, which at that point in time were managing - both setting the goals and managing resources to attain them. Following the aim to exert power and control usurpation, the existing model is deconstructed by the substitution of ideas. It is declared that the highly skilled professionals are inferior to managers and the management should be delegated to managers. This is uttered in an authoritarian style and reminds us that managerialism is an ideology in its essence.

From the above mentioned we can conclude that the higher education sector had objective grounds to approach the internal governance reforms ambiguously. Irrespectively to any other underlying reasons for introducing the new governance model in Latvia, it is clear that this initiative is in line with managerialist policy as well. Observing the deep roots that the managerialism approach has taken in Latvian politics, it is clear that pure collegiality is no longer viable in the higher education sector in Latvia, and different manifestations of managerialism are there to stay. Just a couple of days ago the new internal higher education governance model has been adopted by the government. 
The higher education sector needed to understand the rationale reasons behind the seemingly irrational reforms introduced by the government, as it is the first step to become active co-creators of the future. The next step, but this would be then the subject of further researches, would be to detect the conditions in which the incoming managerialism may undermine or reinforce the quality of higher education, with these conditions to be encountered as early as possible, and in the best way possible - by all involved parties. Since we are one of the last traditional management strongholds in Europe, we will be able to follow the developments and advancements of managerialism in other countries and wield knowledge spillover, as soon as it becomes feasible.

\section{Acknowledgment}

The publication has been elaborated within postdoctoral research project no. 1.1.1.2/VIAA/2/18/296 (European Regional Development Fund).

\section{References}

"Grozijumi Augstskolu likumā" [ "Amendments to the Law on Higher Education"]. (2011, July 14) Retrieved from: https://likumi.lv/ta/id/233707

Arī Rektoru padome prasa izglìtības un zinātnes ministres demisiju [Also the Latvian Rectors' Conference requests the Resignation of the Minister of Education and Science]. (2021, January 06). Latvijas Sabiedriskie Mediji. Retrieved from: https://www.lsm.lv/ raksts/zinas/latvija/ari-rektoru-padome-prasa-izglitibas-un-zinatnes-ministres-demisiju. a387846/

Arnhold, N., Kivistö, J., Püttmann, V., Vossensteyn, H., \& Ziegele, F. (2018a). World Bank Support to Higher Education in Latvia: Volume 2. Internal Funding and Governance. World Bank, Washington, DC. (C) World Bank. Retrieved from: https://openknowledge. worldbank.org/handle/10986/29739 License: CC BY 3.0 IGO

Arnhold, N., Kivistö, J., Vossensteyn, H., Weaver, J., \& Ziegele, F. (2018b). World Bank Support to Higher Education in Latvia: Volume 1. System-Level Funding. World Bank. Washington, DC. (C) World Bank. Retrieved from: https://openknowledge.worldbank.org/ handle/10986/29740 License: CC BY 3.0 IGO

Aslund, A., \& Dombrovskis, V. (2011). How Latvia Came Through the Financial Crisis. Washington, DC: Peterson Institute for International Economics. Retrieved from: Google Scholar, http://scholar.google.com/scholar_lookup?title =How\%20Latvia\%20Came\%20 Though $\% 20$ the $\% 20$ Financial $\% 20$ Crisis\&author $=$ A. $\% 20$ Aslund \&author $=$ V. $\% 20$ Dombrovskis\&publication_year $=2011$

Bennetot Pruvot, E., Estermann, T., \& Kupriyanova, V. (2020). EUA Public Funding Observatory Report 2019/20. Country Sheets. European University Association. Retrieved from: https://eua.eu/resources/publications/914:eua-public-funding-observatory-201920-country-sheets.html

Chong, S., Geare, A., \& Willett, R. J. (2018). Change in a New Zealand university 19852010: Views of collegiality and managerialism. Educational Management Administration \& Leadership, 46(6), 926-941. https://doi.org/10.1177/1741143217717275 
Deklarācija par Artura Krišjāṇa Kariṇa vadītā Ministru kabineta iecerēto darbību [Declaration on the intended activities of the Cabinet of Ministers led by Arturs Krišjānis Kariňš]. (2019). Cabinet of Ministers of the Republic of Latvia. Retrieved from: https:// www.mk.gov.lv/sites/mk/files/media_file/kk-valdibas-deklaracija_red-gala-1.pdf

Dougherty, K. J., Jones, S. M., Lahr, H., Natow, R. S., Pheatt, L., \& Reddy, V. (2014). Performance Funding for Higher Education: Forms, Origins, Impacts, and Futures. The ANNALS of the American Academy of Political and Social Science, 655(1), 163-184. https://doi.org/10.1177/0002716214541042

European Commission. (2019) Education and Training Monitor 2019. Latvia. Luxembourg: Publications Office of the European Union. Retrieved from: https://ec.europa.eu/ education/sites/default/files/document-library-docs/et-monitor-report-2019-latvia_en.pdf

European University Association. (2011). Impact of the economic crisis on European universities In close cooperation with the EUA collective members - National Rectors' Conferences. Retrieved from: https://eua.eu/downloads/publications/impact $\% 20$ of $\% 20$ the $\% 20$ economic $\% 20$ crisis $\% 20$ on $\% 20$ european $\% 20$ universities $\% 20$ january $\% 20$ 2011.pdf

Fisher (Kambah), E. L. (2012, April 09). Academic staff uni's essential resource, not managers. The Sydney Morning Herald. Retrieved from:GSDS https://www.smh.com. $\mathrm{au} /$ politics/federal/academic-staff-unis-essential-resource-not-managers-201204081 wjjb.html

Hodge, S., Holford, J., Milana, M., Waller, R., \& Webb, S. (2018). Economic theory, neoliberalism and the interests of educators, International Journal of Lifelong Education, 37(3), 279-282, DOI: 10.1080/02601370.2018.1484009

Klikauer, T. (2015). What Is Managerialism? Critical Sociology, 41(7-8), 1103-1119. https://doi.org/10.1177/0896920513501351

Ministry of Education and Science of the Republic of Latvia. (2019) Pārskats par Latvijas augstāko izglīību 2019. gadā [Report on Higher Education in Latvia in 2019]. Retrieved from: https://www.izm.gov.lv/lv/media/2122/download

Ministry of Education and Science of the Republic of Latvia. (2020, September 07). Augstākās izglïtibas finansēšanas modelis [Higher Education Funding Model]. Retrieved from: https://www.izm.gov.lv/lv/augstakas-izglitibas-finansesanas-modelis

Pachuashvili, M. (2009). The Politics of Higher Education: Governmental Policy Choices and Private Higher Education in Post-Communist Countries. Central European University. Retrieved from:https://dsps.ceu.edu/sites/pds.ceu.hu/files/attachment/basicpage/478/ mariepachuashviliphdfinal.pdf

OECD. (2019). OECD Economic Surveys: Latvia 2019. OECD Publishing, Paris. https:// doi.org/10.1787/f8c2f493-en

"Par konceptuālo zinnojumu "Par augstskolu iekšējās pārvaldības modeḷa mainu”"“ [“On conceptual report "On internal governance reform of the higher education institutions"']. (2020, March 04). Ministru kabineta rīkojums Nr. 94/ Decree by Cabinet of Ministers No. 94. Retrieved from: https://likumi.lv/ta/id/313034

Quiggin, J. (2003, July 2). Forum for Discussion. Word for Wednesday: managerialism (definition), Commentary on Australian and World Events from a Socialist and Democratic Viewpoint [Blog post]. Retrieved from: https://johnquiggin.com/2003/07/02/word-forwednesday-managerialism-definition/

Rinne, R., \& Koivula, J. (2008). The Dilemmas of the Changing University. In: Final report of EUEREK European Universities for Entrepreneurship: their Role in the Europe of Knowledge. Retrieved from: https://cordis.europa.eu/project/id/506051/reporting/de 
Rutgers, M., \& Schreurs, p. (2006). The Morality of Value- and Purpose-Rationality: The Kantian Roots of Weber's Foundational Distinction. Utrecht Administration \& Society, 38(4), 403-421, DOI: 10.1177/0095399706290632

World Bank. (2014). World Bank Reimbursable Advisory Service on Higher Education Financing in Latvia. Higher Education Financing in Latvia: Final Report. Retrieved from the Ministry of Education and Science of the Republic of Latvia website: https://www.izm. gov.lv/lv/media/2494/download 